\title{
A Method for Measuring the Burn Characteristics of Cigars*
}

\author{
by R. L. Rice and M. Scherbak \\ Imperial Tobacco Limited, Montreal, Quebec, Canada
}

\section{INTRODUCTION}

Methods for determining the rate of burn of cigarettes during smoulder (no puffing, after the initial lighting pulf or puffs) have been described by a number of authors $(x, 2,3)$. The weight of tobacco burned in a puff can also be determined by measuring the total weight of tobacco consumed under a normal smoking regime of intermittant puffing and correcting this weight for that consumed in the free burn period between puffs $(4,5)$. The rate of burn during this free burn period is assumed to be the same as that during smoulder. The burn rates of cigarettes can therefore be well described. Unfortunately, this tednology' cannot be applied to cigars, as the methods cited are dependent upon the measurement of smoulder rate. In general cigats do not smoulder for any extended time - often less than 2 minutes.

In this paper a method will be described whereby the weights of tobacco consumed in the puff and in the free burn period between puffs can be determined. This information is obtained by examining the weights of tobacco burned at different puff frequencies or different puff volumes. Under both conditions of test, the weight of tobacco consumed during free burn is obtained by extrapolation of the data to zero puff frequency or volume. For data at different puff frequencies, the weight of tobacco burned in a puff is obtained by extrapolation of the data to continuous puffing. For data at different puff volumes, the weight of tobacco burned in a puff is obtained directly from the slope of the curve.

\section{EXPERIMENTAL}

The smoking madhine used in this study was built in our laboratory after the design of Williamson and Clark (6). The puff duration and interval between puffs are controlled by automatically reset interval timers.

For most of the development work, one commercial brand of cigar was used. This was a corona type cigar.

During the earlier part of this study it was observed that the weight of the cigar did not affect tate of burn when this rate is expressed as a weight/time relationship. Cigars were therefore weighed but not weight

- Received for publication: 9rh Jure, 1975. selected. The cigars were weighed individually after equilibration at $60 \%$ relative humidity and $72^{\circ} \mathrm{F}$. To obtain a better estimate of cigar weight per unit length, the head end was cut off before weighing.

Before smoking, the cigar was marked at a distance from the tuck end equivalent to $1 / 3$ the length of the cigar. The cigar was extinguished with $\mathrm{CO}_{8}$ at the completed puff cycle closest to this mark. The butt length of the cigar was then measured and the consumed weight calculated. Since it had been observed in the early part of this study that the rate of burn did not change over the length of the cigar, only $1 / 3$ of the cigar was smoked to reduce the time of smoking.

While in this method, puff volume or puff freguency were varied, the following specifications suggested by the International Committee for Cigar Smoke Studies were used as a reference (7):

$$
\begin{aligned}
& \text { Puff volume }-20 \mathrm{ml}, \\
& \text { Puff duration }-1.5 \mathrm{~s}, \\
& \text { Frequency }-40 \mathrm{~s} .
\end{aligned}
$$

\section{RESULTS AND DISCUSSION}

Figure $x$ illustrates the linear relationship of weight of tobacco burned in 40 seconds vs. puff frequency. Each point on the plot represents the mean of three determinations.

Under the conditions of measurement, the weight burned includes that burned both in the puff and in the free burn period between puffs. However, extrapolation of the data to zero puff frequency gives the weight of tobacco burned in 40 seconds of free burn. Similarly, the weight of tobacco burned in a puff can be obtained by extrapolation of the data to 26.7 puffs if it is assumed that the weight of tobacco burned in a puff is directly proportional to puff duration (Figure 1 ). 26.7 puffs/40 seconds is equivalent to a single puff of 40-second duration with no free bum.

The straight line relationship between the weight of tobacco burned in 40 seconds and puff frequency was not unexpected.

The reasons for this assumption are' presented diagrammatically in Figure 2. In this figure, hypothetical relationships between weights of tobacco burned during puffing and during free burn are plotted against puff 
Figure 1. Welght of tobacco consumed per 40 seconds at different puff trequencles.

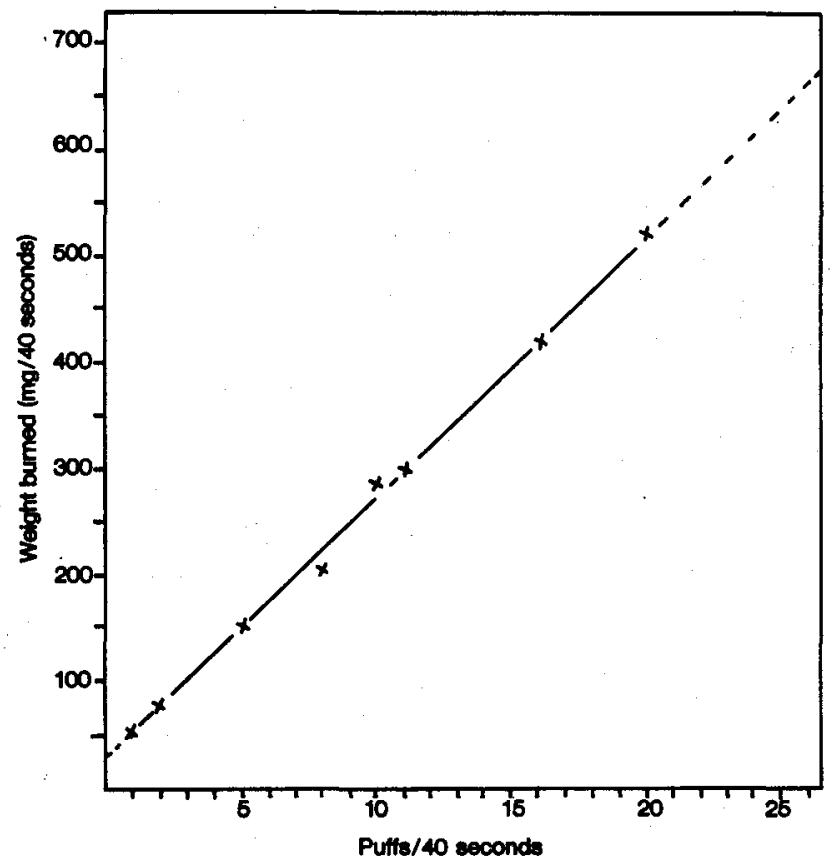

frequency. A $20 \mathrm{ml}$ puff of 1.5 -second duration was assumed. Total time of burn in puffing and in free burn are shown at the base of the figure. These times are solely dependent upon puff frequency.

While the plots are hypothetical, they are not unrealistic and are based on the data in Figure 1 . In this study, the mean rates of burn during a puff were observed to be 20 to 35 times greater than those during free burn.

If puff frequency does not affect burn rates, the following would hold.

1. The total weight of tobacco burned during puffing in any specified period - in this instance 40 seconds - would be directly proportional to puff frequency, BD in Figure 2.

2. The total weight of tobacco burned in free burn in a specified time period would be inversely related to puff frequency, as the total time of free burn decreases with increasing puff frequency, $A C$ in Figure 2.

3. The total weight of tobacco burned, the sum of the two burn conditions, is therefore linearly. related to puff frequency, AD in Figure 2.

In Figure 2, the contribution of free burn to the total weight of tobacco burned in the 40-second time interval is represented by the area $A B D$. It can readily be appreciated that at higher puff frequencies, the weight of tobacco burned under free burn conditions is small relative to that burned during puffing. Therefore even major changes in the rate of free burn would not modify the total weight burned significantly. In fact, it is unlikely that the rate of free burn does remain a constant at higher puff frequencies as the duration of the free burn is probably too short for equilibrium conditions to be established. For example, at a puff
Figure 2. Hypothetical relationships between puff trequency and weights of tobacco consumed in (a) puffing and (b) free burn.

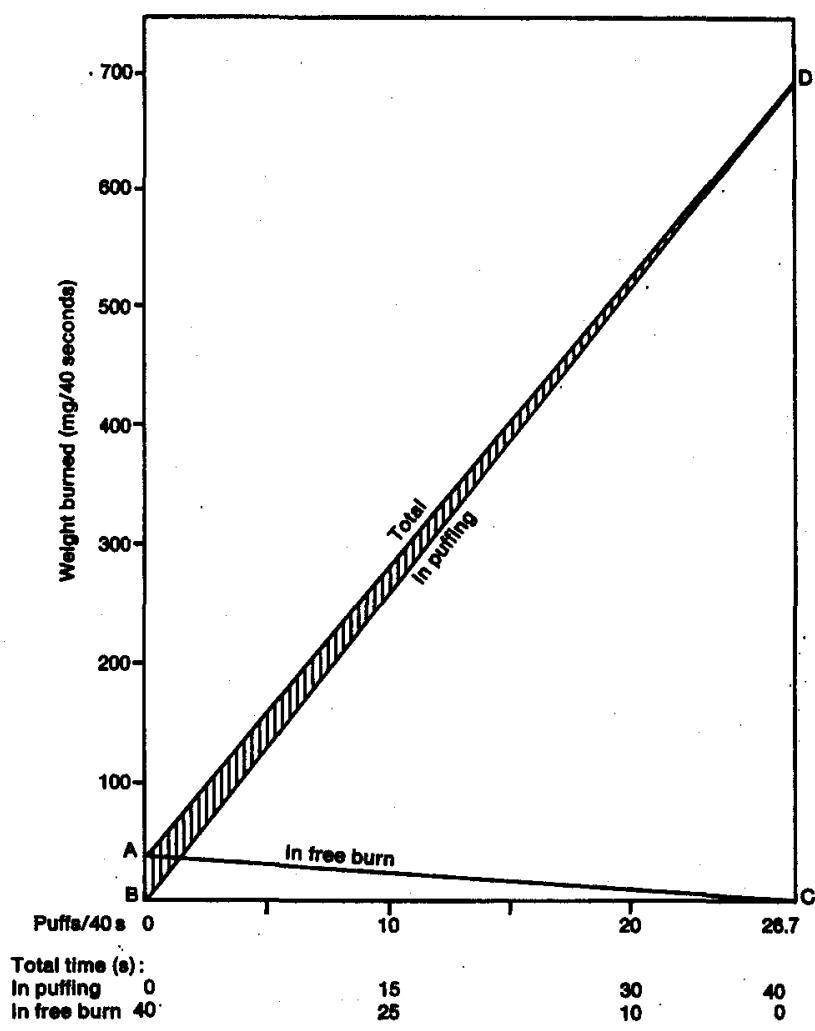

frequency of 15 puffs/40 seconds, the free burn period between puffs is only 1.2 seconds although the total free burn time is 17.5 seconds or $44 \%$ of the total burn time.

The weight of tobacco burned in a puff can also be obtained by calculating for each puff frequency the weight of tobacco consumed in a puff cycle (Table 1 ). At higher puff frequencies, this value approaches a constant. This is the result of the relatively small contribution of the amount consumed during free burn to total weight burned.

An alternative approach to varying puff frequency is to vary puff volume. A plot of weight burned in a puff cycle (one puff of 1.5-second duration and 38.5 seconds of free burn) is plotted against puff volume in Figure 3.

Again the weight of tobacco consumed in free burn is obtained by extrapolation of the data to zero puff

Table 1. Weight of tobacco burned in a puff cycle at different puff frequencles.

\begin{tabular}{c|c}
\hline No. of puffs / 40 seconds & Weight burned (mg) \\
\hline 1 & 46.9 \\
2 & 36.2 \\
5 & 23.5 \\
8 & 19.3 \\
10 & 18.5 \\
16 & 18.8 \\
20 & 18.4 \\
\hline
\end{tabular}


Figure 3. Weight of tobacco consumed per 40 seconds at different puff volumes.

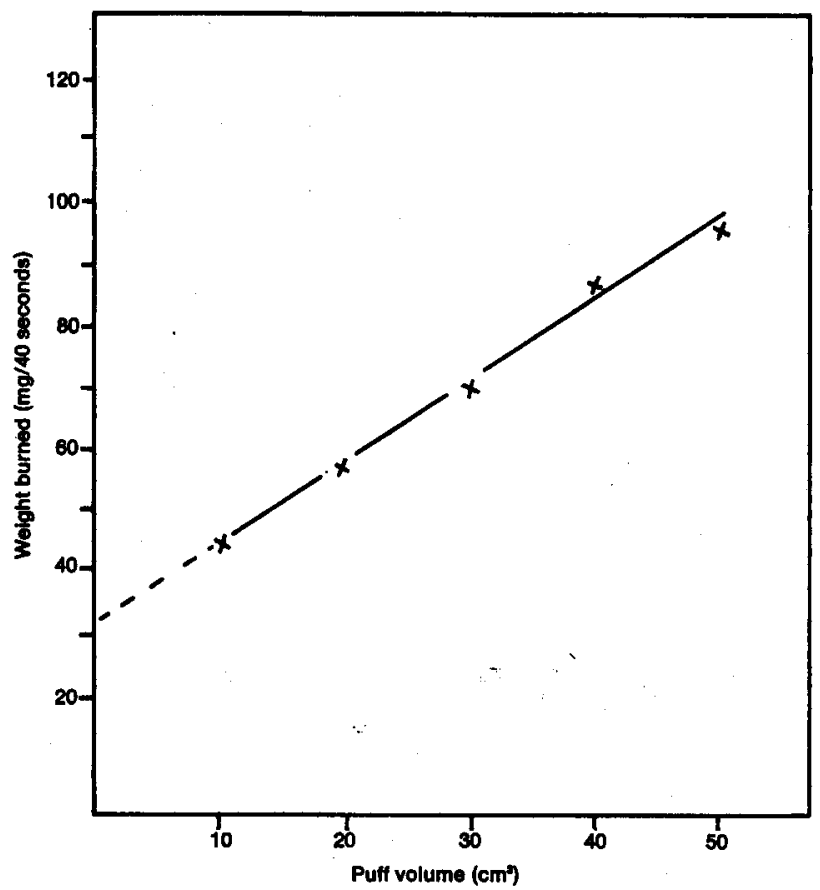

volume. The weight of tobacco burned in the puff at any puff volume is the total weight burned less that burned in free burn.

The weight of tobacco consumed in a puff can also be determined directly from the slope, since the slope represents the weight of tobacco burned (mg) per unit puff volume $\left(\mathrm{cm}^{3}\right)$.

In Table 2 , burn rates obtained by varying puff volume are compared to those obtained by varying puff frequency. The results from the two methods are in good agreement for both rate of free burn and weight of tobacco burned in the puff.

Earlier in this paper, the statement was made that the weight of tobacco burned in a puff cycle was independent of cigar weight. This is demonstrated in a plot of weight burned against cigar weight (Figure 4). It will be observed that the values fall randomly about the mean. Obviously the linear rate of burn will be dependent upon cigar weight. In a previous study it has been observed that the smoulder rate of cigarettes

Figure 4. The effect of clgar weight on rate of burn.

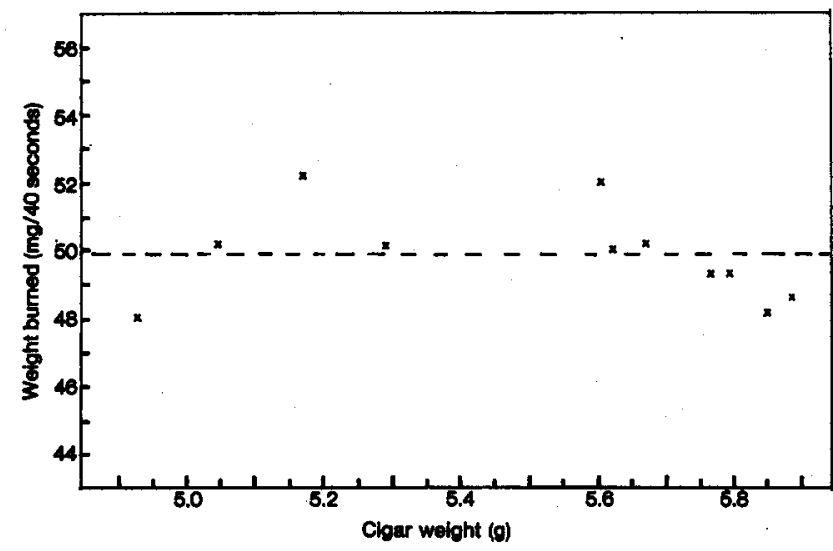

Figure 5. A comparison of rates of burn of different sectlons of the cigar.

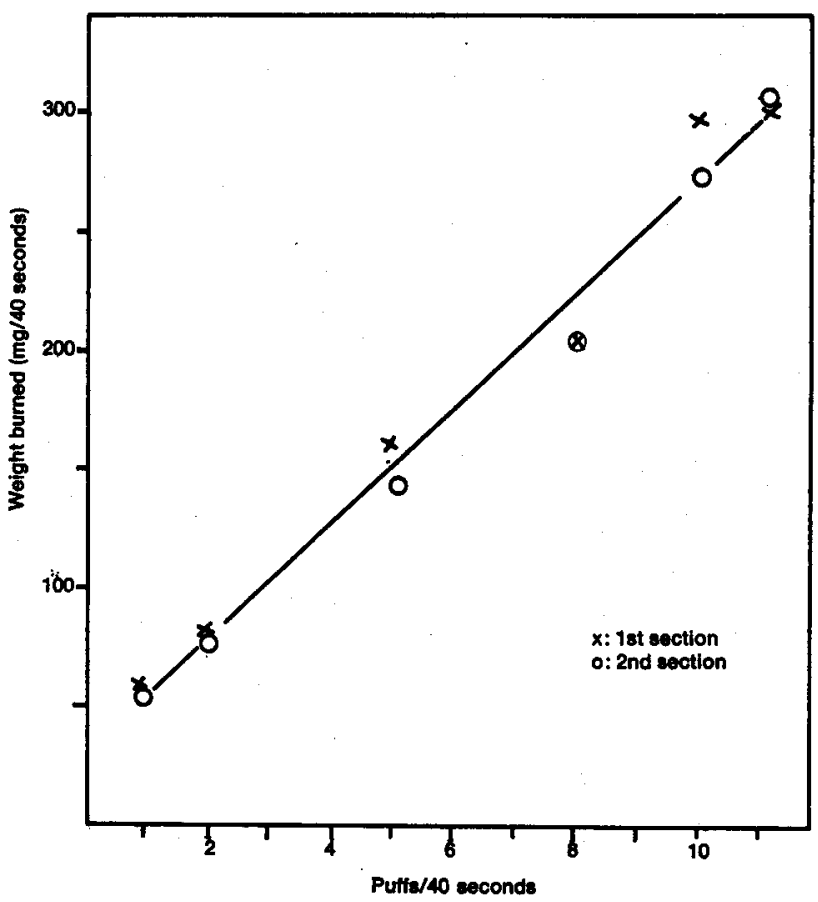

expressed as a weight change rather than a length change is independent of cigarette weight (3).

To compare rates of burn over the length of the cigar, the cigar was marked at distances from the tuck end equivalent to $1 / 3$ and $2 / 3$ of the cigar length. The number of puffs was noted when the leading edge of the coal reached the first mark without interrupting smoking. After the coal reached the second mark, the burn rate was determined according to the routine procedure previously described. It is apparent from the plot of the data from this experiment (Figure 5) that there was little or no difference in the rates of burn for the two sections examined. However, it is not intended to suggest that this is typical for all cigars. In fact a comparison of the rates of burn of different sections of cigar might be an aid in characterizing its burning properties.

Table 2. Comparison of burn rates obtained by varying puff volume and frequency.

\begin{tabular}{c|ccc|c}
\hline \multirow{2}{*}{ Sample } & \multicolumn{2}{|c|}{ Free burn (mg/min) } & \multicolumn{2}{c}{ In puff (mg) } \\
& Frequency & Volume & Frequency & Volume \\
\hline A & 44 & 48 & 25 & 26 \\
B & 36 & 33 & 32 & 35 \\
C & 41 & 39 & 26 & 28 \\
\hline
\end{tabular}

\section{SUMMARY}

For cigarettes, the weight of tobacco consumed in a puff can be determined by measuring the weight of tobacco consumed in a puff cycle (both the puff and free burn period) and correcting this weight for that 
consumed in free burn. The latter is determined independently. This methodology cannot be readily applied to cigars as, in general, cigars do not burn for any extended period under free burn conditions.

In this communication, a method has been described whereby the weights of tobacco consumed in the puff and in the free burn period between puffs can be determined. This information is obtained by examining the weights of tobacco burned at different puff frequencies or different puff volumes. Under both conditions of test, the weight of tobacco consumed during free burn is obtained by extrapolation of the data to zero puff frequency or volume. For data at different puff frequencies, the weight of tobacco burned in a puff is obtained directly from the slope of the curve.

The method provides a means of describing the burning characteristics of a cigar.

\section{ZUSAMMENFASSUNG}

Bei Cigaretten kann die Menge des Tabaks, die während eines Zuges verbraudht wird, dadurch bestimmt werden, daß die Tabakmenge, die in einem Zugzyklus (Zug plus zugfreies Verglimmen) verbraucht wird, gemessen und dieses Gewicht entsprechend der in der Zugpause verbrauchten Tabakmenge korrigiert wird. Letztere wird getrennt bestimmt. Diese Methodik ist nicht ohne weiteres auf Zigarren übertragbar, da Zigarren unter zugfreien Bedingungen im allgemeinen nicht über einen längeren Zeitraum brennen.

In der vorliegenden Arbeit wird ein Verfahren beschrieben, mit dem die Tabakmengen, die während des Zuges und während des zugfreien Intervalls zwischen den $Z$ ïgen verbraucht werden, bestimmt werden können. Diese Information wird dadurch erhalten, daß die Mengen verbrannten Tabaks bei verschiedenen Zugfrequenzen oder verschiedenen Zugvolumina untersucht werden. Bei beiden Untersudiungsbedingungen ergibt sich die Tabakmenge, die während des zugfreien Verglimmens verbraucht wird, durch Extrapolation der Ergebnisse auf die Zugfrequenz oder das Zugvolumen Null. Für Werte bei verschiedenen Zugfrequenzen wird die Tabakmenge, die während eines Zuges verbrennt, direkt durch die Kurvenneigung erhalten.

Mit Hilfe dieser Methode ist es möglich, die Verbrennungscharakteristika einer Zigarre zu beschreiben.

\section{RESUME}

Pour les cigarettes on peut déterminer le poids de tabac consumé dans une bouffée en mesurant le poids du tabac consumé durant un cycle de bouffée (c.-d.-d. la bouffée et la période de combustion libre) et apportant la correction de poids consumé pendant la combustion libre. Ce dernier se détermine indépendamment du premier. On ne peut appliquer cette méthodologie aux cigares, car, en général, ceux-ci ne continuent pas à braler longtemps en combustion libre.

On décrit, dans cette communication, une méthode permettant la détermination du poids du tabac consumé pendant la bouffée et durant la combustion libre entre les bouffées. On obtient cette information en examinant les poids de tabac brâlés à des fréquences différentes de bouffées ou à des volumes différents de bouffée. Dans les deux cas, on obtient le poids de tabac consumé pendant la combustion libre en extrapolant les résultats jusqu'à zéro aussi bien pour la fréquence des bouffées que pour le volume. En ce qui concerne les résultats à différentes fréquences de bouffées, on obtient directement le poìds de tabac brûlé dans une bouffée d'après l'inclinaison de la courbe.

Cette méthode donne un moyen de décrire les caractéristiques de combustion d'un cigare.

\section{REFERENCES}

1. Artho, A. J.: Zur Bestimmung der Glimmrate von Cigaretten; Beitr. Tabakforsch. 3 (1965) 19-24.

2. Kaburaki, Y., H. Kuniyoshi and H. Shigematsu: Instrument for the measurement of cigarette free burning rates; Sci. Papers, Central Res. Inst., Japan Monopoly Corp., No. 109, 171, 1967.

3. Rice; R. L., R. S. Perrier and V. C. Runeckles: A weight loss technique for determining rate of static burn; Tobacco Science XIV (1970) 173-175.

4. Waltz, $P$., and $M$. Häusermann: Untersuchungen zur Rauchmethodik; Mitt. Lebensmitt. Hyg. 51 (1960) 325-338.

5. Backhurst, J. D., and I. W. Hughes: Use of the smoulder rate of a cigarette for determining the weight of tobacco burned during puffing; 16th Tobacco Chemists' Research Conference, Richmond, Virginia, Sept. 26-28, 1962.

6. Williamson, J. T., and P. J. Clark: Eine neue automatische Rauchmaschine zur Einstellung auf die verschiedensten Abraudhbedingungen; Beitr. Tabakforsch. $x$ (xg62) $187-19 x$.

7. Gottscho, A.M.: International studies on cigar smoke; 27th Tobacco Chemists' Research Conference, Winston-Salem, North Carolina, Oct. 3-5, 1973.

The authors' address:

Imperial Tobacco Products Limited, Research Department, P.O. Box 6500, Montreal, Quebec, $\mathrm{H}_{3} \mathrm{C}{ }_{3} \mathrm{~L} 6$, Canada. 